\title{
THE APPLICATION OF STAD- COOPERATIVE LEARNING IN DEVELOPING INTEGRATED SCIENCE ON STUDENTS' WORKSHEET
}

\author{
Titik Rahayu ${ }^{1}$, Syafrimen Syafril ${ }^{2}$, Widya Wati $^{3}$, Yuberti ${ }^{4}$ \\ ${ }^{1}$ Pendidikan Sains, Fakulti Pendidikan, Universiti Kebangsaan Malaysia, Malaysia \\ ${ }^{2,3,4}$ Fakultas Tarbiyah dan Keguruan, Universitas Islam Negeri Raden Intan Lampung, Indonesia \\ e-mail: ${ }^{1}$ p91583@ siswa.ukm.edu.my; ${ }^{2}$ syafrimen@radenintan.ac.id
}

Received 13 July 2017; Accepted 14 October 2017; Published 28 October 2017

\begin{abstract}
The application of Integrated teaching materials in teaching and learning science is very important, to support students acquire comprehensive knowledge and skills and make the learning process more memorable. Teachers must be good at choosing methods and packaging the teaching materials well to attract students' learning interests. This study aims to examine the analysis of the development of integrated Science on Student Worksheet using the steps of cooperative methods of Student Teams Achievement Divisions type. The study was conducted using a qualitative approach (Multi-case single-site case study design). The data were collected through analytical documents and analyzed thematically with NVIVO 10 software. The results showed that the steps to develop integrated science on Student Worksheet using cooperative method of Student Teams Achievement Divisions are: (1) In Student Worksheet there must be motivation and apperception; (2) team building; (3) presentations from teachers; (4) learning activities in teams must be heterogeneous; (5) implementation of individual quizzes; (6) awarding. The results of this study are discussed with various results of previous research.
\end{abstract}

C2017 Physics Education, FTK UIN Raden Intan Lampung

Keywords: Integrated Science, type STAD - cooperative learning, students worksheet.

\section{INTRODUCTION}

Science is not only stressed on the mastery of knowledge, i.e., factual, concept, or principles solely, but also is a process of scientifical discovery, science learning is related of how to find out about nature systematically (Kurikulum, 2006). According to (Trianto, 2011) science is built for the scientific product, scientific process, and scientific attitude. Due to achieve science learning purpose is needed various learning material and supporting facility, one of it is the used of Students Worksheet. Students Worksheets is a printed learning material that prepared and used by the teachers to assist students in achieving knowledge, skills, and values. Science learning can involve students and learning process can be active and efficient (Lee, 2014; Sasmaz-Oren, 2012).
Some research gained that in several countries Students Worksheet becomes the booster of the curriculum (Martin, 2012). However, integrated science that discussed in this research is the integration of material by science terminology which exists on Al-Qur'an. The needed for the facility of learning methods also proper learning tools is necessary to deliver integrated science (Rahayu.P, 2012). According (Rimma A. Kutbiddinova, 2016) with methods will connect the interaction between teachers and students, e.g., in cooperative learning methods will occur discussion group, debate, simulation game, business, situation analysis case, project methods, social-psychologist training, moderation and computer simulation. STAD-cooperative type assumed can increase students learning achievement, social relation, grow the 
attitude of accepting excess and weakness of self and other, also increasing students self-concepts (R. E. Slavin, 2011).

The selection of this method is based on some research results about the use of STAD-cooperative type which is associated with many academic achievements, social attitudes, interactions and interpersonal relationships. (Bernaus, 2008). Hence, in STAD-cooperative type students feel appreciated when issuing ideas in their minds because the team succeeds in STAD-cooperative type depends on individual succeed from all members of that team (Jacobs, 2006).

Students Worksheet is sheets that consist assignments that students must do (Majid, 2008; Saregar, 2016). The involvement of students on developing and using Students Worksheet assist them along the learning process (Gunes, 2005; Tutak, 2008a, 2008b), then ensure students to learn in the learning environment (Bak-Kibar, 2010a, 2010b). Therefore, the used of Students Worksheet in learning makes students easier in understanding the problem of a learning topic (Bozdogan, 2007). Printed base text formed Student Worksheet needs six elements, they are; consistency, format, organization, appeal, font size, and empty space usage (Arsyad, 2013). Some research get that interested Students Worksheet is a worksheet with cartoon images (Burhan, 2008; Karamustafaoglu, 2005), conceptual images, and evaluation question (Karamustafaoglu, 2005), it is because evaluation question is an essential factor in Students Worksheet (Calderhead, 2006).

The facts, in school, show that the integrated science Students Worksheet is still very minimal elements presented so that students are less interested in using Students Worksheet in the learning process. That the teacher gives a sheet of Students Worksheet to the students only when doing the activity and the Worksheet that is used unfulfill the elements that explained before. The research (Kisiel, 2003b) found that students will not learn if they do not have Students Worksheet. Fry (1987) on his research showed that the teachers agreed Students Worksheet is using as learning facility, able to handle learning difficulty, and increasing learning experience. Some of the experts found that students feel challenging to understand physics material individually, worst teaching methods, unskills students, etc. (Ajaja, 2002; Jegede, 2007; Yusuf, 2010). Hence, on learning the team, not all teamwork cooperatively (Van Wyk, 2010). So, Along the learning process, teachers must select the methods, technique, and learning material correctly so the aims can be achieved (Sugiharto, 2015). Based on that point of view, the researcher select method and technique based on STAD-cooperative type and learning material in the form of Students Worksheet.

Students Worksheet development using STAD-cooperative type assumed can assist the solution of learning problems. Learning process uses this approach can cope the students with a group member so that they can cooperate effectively (Amornsinlaphachai, 2012; Anowar Hossain, 2013; Kasíková, 2007; Macarena Navarro-Pablo, 2015). This is also able to increase students understanding because they work in achieving the aims together, i.e., social skill, to achieve and master the concept and the teaching material that students designed (Sugiharto, 2015). In addition, problems solving on physics material is easier to be done on the team rather than individual learning (Jonassen, 2001). The experts report that STAD-cooperative type is more effective than individual strategic learning, discussion methods, and conventional instruction class (Keramati, 2010; Taiwo, 2008), it is because cooperative learning can assist students to improve verbal communication, and their social skills 
(Monchai Tiantong \& Sanit Teemuangsai, 2013). So, the cooperative learning interest is an increase in the next years (Elif Akdemir, 2012).

\section{METHOD}

This research is done with using qualitative approach(Multi-case singlesite case study design). The data collected through analysis document (Darlington, 2002). The document used as the data source and as proving, analyzing, and interpreting the case (Moleong, 2007). Furthermore (Moleong, 2007) gives the reasons of why document analyses are important in qualitative research; (1) is a constant source, well and supporting, (2) as evident in testing, (3) natural, contextual, overt and in the context, (4) cheap and not hard to find, it only takes time, (5) opens the opportunity to broaden knowledge of the issues under study. All data obtained through the document are analyzed by thematic help with software NVIVO 10. Below on diagram 1 showed diagram plot on resulting the proper stages that can be applied to Integrated Science on Students Worksheet.

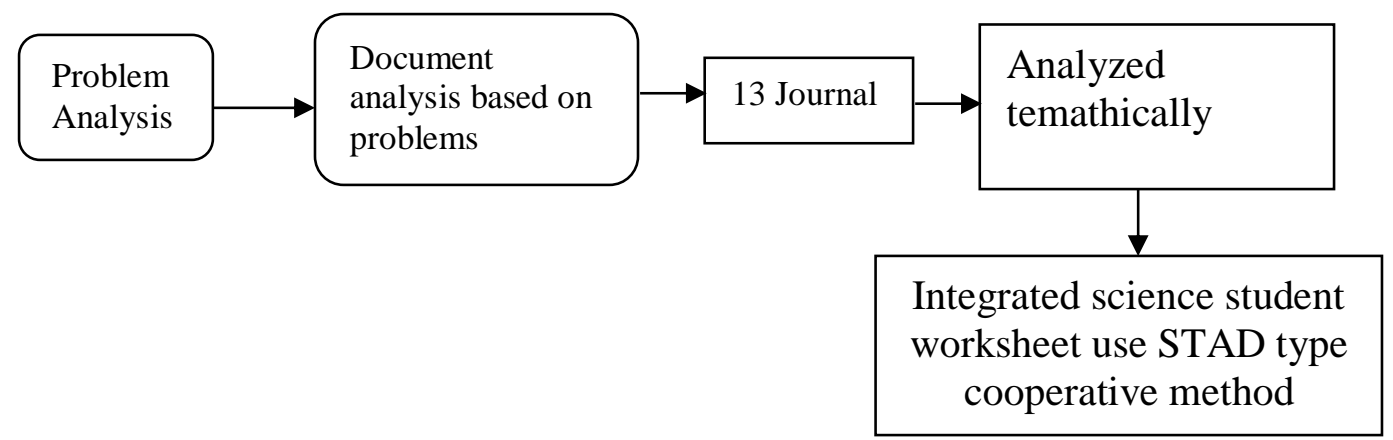

Figure. 1 Developing Plot Integrated Science on Students Worksheet.

\section{RESULT AND DISCUSSION}

The research findings show that the developing stages of Integrated Science on Students Worksheet using STADcooperative type method based on document analysis (Isiaka Amosa Gambari, 2015; Mohamad Nur, 2005; R. Slavin, K \& Oickle, 1981; R. E. Slavin, 1978, 1983, 1988; R. E. Slavin, 1990; R. E. Slavin, 1991; R. E. Slavin, 1995, 2005, 2008; Sugiyanto, 2007; Monchai Tiantong1 \& Sanit Teemuangsai, 2013) that Students Worksheet must consist; First, motivation and apperception giving; teacher delivers the aims of study also giving motivation to the students in achieving learning competency and aim. The decision of motivation and apperception in Integrated Science on Students Worksheet, the research looks on the syllabus as writing guidance. Second, team building; it is very important in
STAD-cooperative type. Third, teachers' presentation; in this case, the researcher analyzes syllabus and see the indicators that the students will achieve. Fourth, learning activity in the team must be heterogeneous. Fifth, implementation of the individual quiz; the researcher analyze based on syllabus and learning achieve indicators. Sixth, reward giving; the stages in rewarding on the team are. (a) Deciding basic score (initial) of each student; (b) Deciding test or quiz score that was done after the students work in a group, i.e., first quiz score, second quiz score, the average first quiz score the average second quiz score. (c) Deciding increasing learning result score which decided according to the difference of quiz score and a basic score of each student by using conversion of students achievement towards the contribution of their team. 
The proper learning material and Students Worksheet is a set that gives information learning experience, developed with good character and (Tomlinson, 2012). He also implies that Students Worksheet is an informative set (informing the learning aims), there is a learning method (face to face learning and practice), formulate experience, motivation, and exploration. However, this point of view is in line with the research result that the developing of Integrated Science on Students Worksheet have different characteristics and designed suit to the good Students Worksheet writing guidance. Developing characteristics of integrated science on Students Worksheet is on Students Worksheet implied on written stages STAD-cooperative type. The researcher agrees with the perspective (Tomlinson, 2012) that the first developing stages of Integrated Science on Students Worksheet is motivation and apperception giving.

Research findings (Fajola, 2000) and (Ghaith, 2003) find that cognitive, affective and psychomotorics skill achievement of male students is better than female students. It showed that there is a correlation between gender, ethnicity or race and academic achievement in science learning. The result of developing integrated Science on Student Worksheet using STAD-cooperative type one of the stages is forming learning team. Learning team in STAD-cooperative type is heterogeneous, which is based on gender, achievement level, ethnicity or race, and other students characteristics (R. E. Slavin, 2011). Each team consists of 4 or 5 students, then take the individual quiz, and calculate the team improvement in order to see how far the understanding level of students.

Later, developing stages of integrated Science on Students Worksheet STADcooperative type is learning activity inside learning team (heterogeneous group). The teachers do team forming, and students are not allowed to form their own group (R. E. Slavin, 1988). He also admits that grouping must be balanced (R. E. Slavin, 1988). Yu on his research found that subject in team STAD-cooperative type has a higher score on posttest and questionnaire (Yu, 1998). Strengthen by Noornia, that learning team STADcooperative type brings a positive effect to students learning activity, giving improve students comprehension, giving special knowledge towards smart students team and less smart students team, boost every team to have sympathy to the others (Noornia, 1997). Besides, on STAD students not only do team task but also learn to be a team (M. Nur, 2008). So, the researcher concludes that by developing integrated Science on Students Worksheet with STAD-cooperative type, will be very helpful for students. Each student as a team member is able to learn to position themselves, cooperate, socialize, respect other teams' idea, and able to learn to apply STAD-cooperative type value characteristics on the team to achieve learning aims.

Some researchers offer to apply STAD-cooperative type as the main method that applied on class (Johnson, 1975; Sharan, 1979; R. E. Slavin). (Featherstone, 1986) On his research gained that cooperative learning able to help students, because on the team all students able to improve their understanding by explaining their ideas to others. Then, the task on the cooperative team is not only to fill the Students Worksheet but also to understand material learning concepts (R. Slavin, K, 2010; R. E. Slavin, 2011). He also finds that students on cooperative learning are more able to socialize not isolated, interesting, not dull (R. E. Slavin, 2011). These findings allow the researcher to use the cooperative method, so the learning will not be dull and students able to improve their social sense of learning team.

\section{CONCLUSION AND SUGGESTION}

According to the analysis that has been done towards several documents (journal) the researcher concludes in order to create 
a comprehensive and interesting learning environment, the teacher must be creative and skilfull in taking action from various problems faced by students.

Moreover, the teacher must good in choosing learning methods as the experts ever used previously. If teachers already able to apply it, thus, the learning process will be meaningful and interested for students.

\section{REFERENCES}

Ajaja, O. P. (2002). Assessment of biology study support environments in schools. In STAN 41st Annual Conference Proceedings, 215-218.

Amornsinlaphachai, P. a. D., K. (2012). Developing the Model of WebBased Learning Environment Enhancing Problem-Solving for Higher Education Students. American Journal of Scientific Research, 52, 21-32.

Anowar Hossain, R. A. T. (2013). Effects of cooperative learning on students' achievement and attitudes in secondary mathematics. Procedia Social and Behavioral Sciences, 93(2013), 473 - 477.

Arsyad, A. (2013). Media Pembelajaran. Jakarta: Raja Grafindo Remaja.

Bak-Kibar, Z. v. A., A. (2010a). Developing a worksheet about physical and chemical event. Procedia Social and Behavioral Sciences, 2, 739-743.

Bak-Kibar, Z. v. A., A. (2010b). Implementing of a worksheet related to physical and chemical change concepts. Procedia Social and Behavioral Sciences, 2, 733-738.

Bernaus, M. G., R.C. (2008). Teacher motivation strategies, student perceptions, student motivation, and English achievement. The Modern Language Journal, 92, 387-401.
Bozdogan, A. (2007). Fen bilgisi ogretiminde calısma yaprak-ları ile ogretimin ogrencilerin fen bilgisi tutumuna ve mantıksal dusunme becerilerine etkisi. Yayimlanmamis yuksek lisans tezi, Cukurova Universitesi, Sosyal Bilimler Enstitusu, Adana.

Burhan, Y. (2008). Developing worksheets enriched by concept cartoons concerning the acid-base concepts. Karadeniz Technical University Graduate School of Natural and Applied Sciences.

Calderhead, W. J., Filter, K. J., \& Albin, R. W. (2006). An investigation of incremental effects of interspersing math items on task-related behavior. Journal of Behavioral Education, 15(1), 51-65.

Darlington, Y. S., Dorothy. (2002). Qualitative Research in Practise: Stories From the Field. Crows Nest: Allen \& Unwin.

Elif Akdemir, A. A. (2012). From Past to Present: Trend Analysis of Cooperative Learning Studies. Procedia - Social and Behavioral Sciences, 55(2012), $212-217$.

Fajola, O. O. (2000). Effect of three modes of computer Based instructional strategies on students learning outcomes in biology. University of Ibadan, Ibadan, Nigeria. Retrieved from Unpublished Ph.D thesis

Featherstone, H. (1986). Cooperative learning. Harvard Education Letter, 4-6.

Ghaith, G. (2003). Effects of the learning together model of cooperative learning on English as a Foreign Language reading achievement, academic self-esteem, and feelings of school alienation, American University of Beirut. Bilingual Research Journal, 27(3). 
Gunes, G. v. A., A. (2005). Olusturmac1 yaklasima gore ta- sarlanan ogrenme ortamının matematik basarısına etkisi. Gazi Universitesi, Gazi Egitim Fakultesi Dergisi, 25 (1), 105-121.

Isiaka Amosa Gambari, M. O. Y., David Akpa Thomas. (2015). Effects of Computer-Assisted STAD, LTM and ICI Cooperative Learning Strategies on Nigerian Secondary School Students' Achievement, Gender and Motivation in Physics. Akpa Malaysian Online Journal of Educational Sciences, 3, 11-26.

Jacobs, G. (2006). Cooperative Learning and Second Language Teaching. Cambridge University Press.

Jegede, S. A. (2007). Student's anxiety towards the learning of Chemistry in some Nigerian secondary schools. Educational Research and Review, 2(7), 193-197.

Johnson, D. W., \& Johnson, R. T. (1975). Learning together and alone. Englewood Cliffs, New Jersey: Prentice-Hall, Inc.

Jonassen, D. K., H. (2001). Communication patterns in computer-mediated versus face-to-face group problem solving. Educational Technology Research \& Devt, 49(11), 35 - 51.

Karamustafaoglu, O., Yaman, S. ve Karamustafaoglu, S. (2005). Fen ve teknoloji egitiminde ogrenme ve ogretim materyalleri. M. Aydogdu ve T. Kesercioglu (Ed.), Ilkogretimde fen ve tekno-loji ogretimi icinde 212234.

Kasíková, H. (2007). Kooperativní učení a vyučování. Teoretické a praktické problémy. Univerzita Karlova $\mathrm{v}$ Praze : Karolinum.

Keramati, M. (2010). Effect of cooperative learning on academic achievement of physics course. Journal of
Computers in Mathematics and Science Teaching, 29(2), 155 -173.

Kisiel, J. (2003b). Teachers, museums and worksheets: A closer look at a learning experience. Journal of Science Teacher Education, 14(1), 3-21.

Kurikulum, P. (2006). Pembelajaran Tematik. Jakarta: Departemen Pendidikan Nasional

Lee, C. D. (2014). Worksheet usage, reading achievement, classes' lack of readiness and science achievement: A cross-country comparison. International Journal of Education in Mathematics, Science and Technology, 2(2), 96-106.

Macarena Navarro-Pablo, E. J. G.-S. (2015). Teaching to training teachers through cooperative learning. Procedia - Social and Behavioral Sciences, 180(2015), $401-406$.

Majid, A. (2008). Perencanaan Pembelajaran Mengembangkan Standar Kompetensi Guru. Bandung: PT. Rosdakarya.

Martin, M. O., Mullis, I. V. S., Foy, P, \& Stanco, G. M. (2012). TIMSS2011 international results in science. Chestnut Hill, M.A: TIMSS \& PIRLS International Study Center.

Moleong, L. J. (2007). Metodologi Penelitian Kualitatif. Bandung: PT Remaja Rosdakarya Offset.

Noornia, A. (1997). Implementation of Cooperative Learning with STAD Method in Teaching Percent in Class IV SDI Maarif 02 Pematang Singosari. Malang.

Nur, M. (2005). Pembelajaran Kooperatif. Surabaya: Pusat Sains dan Matematika Sekolah UNESA.

Nur, M. (2008). Cooperative Learning. UNESA, Surabaya 
Rahayu.P, S. M., dan Miswadi. (2012).

Pengembangan Pembelajaran IPA

Terpadu Dengan Menggunakan

Model Pembelajaran Problem Base

Melalui Lesson Study. Program

Pascasarjana.

Rimma A. Kutbiddinova, A. A. E., Marina A. Romanova. (2016). The Use of Interactive Methods in the Educational Process of the Higher Education Institution. International Journal of Environmental \& Science Education, 11(14), 6557-6572.

Saregar, A. (2016). Pembelajaran Pengantar Fisika Kuantum dengan Memanfaatkan Media PhET Simulation dan LKM Melalui Pendekatan Saintifik: Dampak pada Minat dan Penguasaan Konsep Mahasiswa. Jurnal Ilmiah Pendidikan Fisika Al-Biruni, 5(1), 53-60.

https://doi.org/10.24042/jpifalbiruni. v5i1.105

Sasmaz-Oren, F. O., U. . (2012). An application about pre-service teachers' development and use of worksheets and an evaluation of their opinions about the application. Educational Sciences: Theory and Practice, 12(1), 263270.

Sharan, S. (1979). Cooperative learning in teams:A Critical review of 'recent methods and effects on achievement,attitudes, and racelethnicrelations: Unpublished manuscript.

Slavin, R., K. (2010). Cooperative Learning. Universitas Johns Hopkins: Baltimore, MD, AS.

Slavin, R., K \& Oickle. (1981). Effectsof Cooperative Learning Teams on Studen Achievement and Race
Relations:Treatmentby Race Interactions. Sociology of Education, 54, 174-180.

Slavin, R. E. Cooverative Learning.Review of Educational Research,vs. in press.(a).

Slavin, R. E. (1978). StudentTeamsand Achievement Divisions. Journal of Researchand Development in Education, 12, 39-49.

Slavin, R. E. (1983). Student Team Learning: An Overview and Practical Guide. Washing-ton, D.C: National Education Association.

Slavin, R. E. (1988). Student team learning: An overview and practical guide (2 ed.). Washington D.C: National Education Association.

Slavin, R. E. (1990). Cooperative learning: Theory, research, and practice. Englewood Cliffs, NJ: Prentice Hall.

Slavin, R. E. (1991). Student team learning: A practical guide to cooperative learning (3 ed.).

Slavin, R. E. (1995). Cooperative Learning : Theory, Research and Practice. Massachusetts: Allyn and Publishers.

Slavin, R. E. (2005). Cooperative learning: Theory, research, and practice. Englewood Cliffs, NJ: Prentice Hall.

Slavin, R. E. (2008). Cooperative learning: Theory, research, and practice. Englewood Cliffs, NJ: Prentice Hall.

Slavin, R. E. (2011). Instruction Based on Cooperative Learning. In $R$. E. Mayer, \& P. A. Alexander (Eds.), Handbook of Research on 
Learning and Instruction. New York: Taylor \& Francis.

Sugiharto. (2015). The Effect of Cooperative Learning Model and Kolb Learning Styles on Learning Result of The Basics of Politics. Journal of Education and Practice, $6(21)$.

Sugiyanto. (2007). Modul Guruan dan Latihan Profesi Guru (PLPG), Model-model Pembelajaran Inovatif. Panitia Sertifikasi Guru Rayon 13 Surakarta.

Taiwo, O. A. (2008). Relative effectiveness of ICI and CCI packages on the performance of students in senior secondary school mathematics in Minna. Unpublished B.Tech. Project, Department Science Education, Federal University of Technology, Minna.

Teemuangsai, M. T. S. (2013). Student Team Achievement Divisions (STAD) Technique through the Moodle to Enhance Learning Achievement. International Education Studies by Canadian Center of Science and Education, 6(4).

Teemuangsai, M. T. S. (2013). Student Team Achievement Divisions (STAD) Technique through the Moodle to Enhance Learning Achievement. International Education Studies, 6.

Tomlinson, B. (2012). Material Development for Language Learning and Teaching. Cambridge Journal Lang Teach, 45(2), 143-179.

Trianto. (2011). Model Pembelajaran Terpadu Konsep,Strategi dan Implementasinya dalam Kurikulum Tingkat Satuan Pendidikan (KTSP). Jakarta: Bumi Aksara.
Tutak, T. v. B., O. (2008a). Dinamik geometri yazılımı ile geometri ogretiminin ogrencilerin van heile geometri anlama du-zeylerine etkisi. 8th International Educational Technology Conference, Eskisehir(1058-1061).

Tutak, T. v. B., O. (2008b). Geometri ogretiminde bilgisa-yar destekli ogretimin ogrenci basarısina etkisi. 8th International Educational Technology Conference (s. 10621065), Eskisehir. Van Wyk, M. M. (2010). Do student teams achievement divisions enhance economic literacy? A quasiexperimental design. Journal of Social Science, 23(2), 83-89.

Yu, F. Y. (1998). The Effects of Cooperation With Inter-Group Competition on Performance and Attitudes in a Computer-Assisted Science Instruction. Journal of Computers in Mathematics and Science Teaching, Charlottesville, VA: AACE., 17(4), 381-395.

Yusuf, M. O., \& Afolabi, A. O. (2010). Effects of Computer Assisted Instruction (CAI) on Secondary School Students' Performance in Biology. The Turkish Online Journal of Educational Technology, 9(1). 